Article

\title{
Do Urban Rail Transit Facilities Affect Housing Prices? Evidence from China
}

\author{
Xu Zhang ${ }^{1, *}$, Xiaoxing Liu ${ }^{1}$, Jianqin Hang ${ }^{2}$, Dengbao Yao ${ }^{1}$ and Guangping Shi ${ }^{1}$ \\ 1 School of Economics and Management, Southeast University, Nanjing 211189, China; \\ morningstar168@seu.edu.cn or starsunmoon198@163.com (X.L.); yaodengbao@126.com (D.Y.); \\ shigp1210@126.com (G.S.) \\ 2 School of Economics and Management, Jiangsu Maritime Institute, Nanjing 211170, China; \\ jianqinhang@126.com \\ * Correspondence: 230149142@seu.edu.cn or zx8387@126.com; Tel.: +86-25-5209-0731
}

Academic Editor: Yehua Dennis Wei

Received: 28 January 2016; Accepted: 14 April 2016; Published: 18 April 2016

\begin{abstract}
Urban rail transit facilities play a critical role in citizen's social activities (e.g., residence, work and education). Using panel data on housing prices and urban rail transit facilities for 35 Chinese cities for 2002 to 2013, this study constructs a panel data model to evaluate the effect of rail transit facilities on housing prices quantitatively. A correlation test reveals significant correlations between housing prices and rail transit facilities. Empirical results demonstrate that rail transit facilities can markedly elevate real estate prices. Quantitatively, a $1 \%$ increase in rail transit mileage improves housing prices by $0.0233 \%$. The results highlight the importance of other factors (e.g., per capita GDP, land price, investment in real estate and population density) in determining housing prices. We also assess the effects of expectations of new rail transit lines on housing prices, and the results show that expectation effects are insignificant. These findings encourage Chinese policy makers to take rail transit facilities into account in achieving sustainable development of real estate markets.
\end{abstract}

Keywords: rail transit; housing price; expectation; panel data

\section{Introduction}

In recent decades, residential conditions have been a critical factor of the formation of sustainable cities [1]. Vast price bubbles in real estate markets increase the risk of bubbles bursting, which may damage the sustainable urban development. Meanwhile, urban rail transit facilities play an important role in alleviating traffic pressures [2] and promoting sustainable urban development [3], which may expand city boundaries. Accordingly, it is of enormous interest to ask whether urban rapid rail transit affects housing prices.

Starting in the early 2000s, a housing boom coupled with strong economic growth emerged in China. However, affected by the global financial crisis of 2008, the Chinese housing market dipped into a short recession. Following the institution of a series of economic stimuli (e.g., expansionary fiscal and monetary policies), China's real estate market quickly recovered. Recently, whether a bubble in China's housing market exists has been discussed by Shen [4], Ren et al. [5], and Feng et al. [6]. Economic fundamentals [7,8], regional productivity [9], monetary [10], demographic [11,12], and behavioral factors [13] are recognized as major determinants of housing values. More recently, impacts of transit factors on real estate values have attracted broad interest from transportation researchers and policymakers around the world.

At present, however, whether urban rail transit plays a critical role in determining housing values still remains controversial, though some case studies [14] provide supporting evidence. Zhang et al. [14] examine the capitalization of transit access in Beijing and find that the premium 
of metro rail transit is 248.31 yuan $/ \mathrm{m}^{2}$ for every $100 \mathrm{~m}$ closer to a metro station. Similar results are presented by Hewitt and Hewitt [15], Jun [16], Kim and Lahr [17] and Chatman et al. [18]. However, Seo et al. [19] claim that proximity to a light rail transit station has both positive (i.e., accessibility to a rail transit station) and negative effects (i.e., air pollution and noise).

Urban rail transit in China has entered a phase of rapid expansion since the start of this century, during which the real estate market has experienced a golden era. Although some case studies provide supporting evidence for impacts of urban rail transit on housing prices, this issue has not been researched adequately, especially for China, where urban rail transit facilities and economic growth have boomed over the past decades. As of today, however, little panel data evidence exists on the relationship between rail transit facilities and housing prices at the city level. In this paper, we propose a theoretical framework and employ a panel model to examine the impacts of urban rail transit on housing prices. Our work contributes to the existing literature in several ways. First, we collect annual rail transit mileage records for operations of each sampled city, and we conduct a correlational analysis of rail transit facilities and housing prices in China. Second, we extend existing research on this relationship using panel data at the city level (Rail transit mileage refers to the length of rail transit that has been in service.). More specifically, we employ a panel model to assess the significance of the effects of rail transit on real estate prices. Third, we study the influence of rail transit expectations on housing booms. Fourth, we compare the effects of various factors (e.g., economic fundamentals, demographic factors, educational resources and urban rapid transit) on housing prices.

The remainder of the paper is organized as follows. Section 2 reviews existing literature related to the determinants of urban housing prices. Section 3 presents a brief description of the development of urban rail transit systems in China and a correlational analysis of housing prices and rail transit facilities. Section 4 describes model and data used. Section 5 estimates the panel data model and discusses the results. Section 6 provides the study's conclusions and implications.

\section{Literature Review}

Our study touches on two strands of literature: micro- and macro-level studies on determinants of housing prices. Micro-level studies are typically conducted by case studies, which are usually based on a hedonic house modelling and estimated by cross-sectional micro-level data. In contrast, macro-level studies, in most cases, focus on economic determinants of average urban housing prices, which are usually conducted by panel data model or time series model.

\subsection{Micro-Level Studies on Housing Prices}

In regard to the first strand of literature, a number of studies have focused on whether and how transportation, amenity, education, building structure and distance to the central business district (CBD) affect housing markets. For the literature on transportation, some studies assess the effects of subway, light rail transit and other transportation facilities on housing prices. For example, Andersson et al. [20] assess the implicit housing price of a new high-speed railway line (HSR) that connects seven metropolitan areas in Taiwan using a hedonic price function. Their results show that HSR accessibility has at most a minor effect on house prices. Zhang et al. [14] study the capitalization of transit access in Beijing. In their study, they divide urban mass transit into three categories: bus rail transit (BRT), light rail transit (LRT) and metro rail transit (MRT). These researchers' results demonstrate that MRT has the highest premium on housing prices, that LRT has a moderate premium, and that BRT has the lowest premium. Similar studies include Lewis-Workman and Brod [21], Zheng and Liu [22], Zhang et al. [23], Zhang [24], Hewitt and Hewitt [15] and Kim and Lahr [17].

Using an approach similar to De Vany [25], Seo et al. [19] construct a theoretical model on how amenity and disamenity should decay differently from links and nodes of rail and road networks. The authors thus examine the effects of nodes and links on housing prices. Their study shows that proximity to transport nodes is significantly and positively associated with housing prices. As a function of distance from highway exits and LRT stations, distance-band coefficients are found to form 
an inverted-U pattern consistent with positive longer-range distance-decay accessibility effects minus smaller, shorter range distance-decay disamenity effects.

For the case of China, educational resources, among the various factors that influence real estate prices, are a key consideration for home buyers, which differs from the case of other countries due to the "school district" policy for primary school students (In China, primary school students are limited to attend school near their residence, and the district owns high-quality primary schools known as a "school district house"). As a result, "school district house" has become a focal social issue and has conjured heated discussions between economics and sociological scholars. Wen and Jia [26] construct a hedonic model that included 15 housing feature variables. Their results show that the proxy variables of school and kindergarten have insignificant effects on housing prices. Feng and $\mathrm{Lu}$ [27] conduct a case study on Shanghai using panel data on 52 regional distributions of high schools. Their findings provide sufficient evidence that housing prices to some extent depend on one's distance from a high school and on the quality of nearby schools. Wen et al. [28] conduct a more detailed case study on Hangzhou, China and find that educational facilities have positive capitalization effects on housing prices. In addition, some studies have revealed significant links between housing prices and structural characteristics of real estate markets (e.g., vacancy rates, construction permits, and building ages) $[3,28,29]$.

\subsection{Macro-Level Studies on Housing Prices}

Macro-level studies on determinants of housing prices are quite extensive. According to the existing literature, the major macro determinants of housing price can be divided into two categories: economic fundamentals and demographic factors. Related empirical studies initially focused on economic factors. Fortura and Kushner [30] find a significant positive correlation between income and housing prices. Quigley [29] assesses the effects of per capita income, employment, and other variables on housing prices. The model shows that these factors can explain $10 \%-40 \%$ of housing price variations. The model also suggests that the lagged housing price can be served as an important factor in determining housing price. Zou and Chau [31] claim that the consumer price index (CPI) is a long-term determinant of house prices. At the national level, business cycles, industrial production levels and employment rates are also the main factors which contribute to the change in housing prices [32-34]. More recently, monetary variables such as monetary supplies and interest rates have been found to be associated with housing prices [10,35].

As a component of housing costs, land prices are considered to be significantly associated with housing prices. Yang [36] and Bao [37] claim that the rise in land prices has increased housing prices. Wen and Goodman [38] construct a simultaneous-equations model to examine the interplay between housing and land prices. Their model was estimated using sample data on 21 provincial cities in China from 2000 to 2005, and their results show that housing and land prices are endogenously interrelated. Du et al. [39] employ a Granger causality approach to test this relation. Their results suggest the presence of unidirectional Granger causality between housing and land prices.

Demographic factors are recognized as major determinants of urban housing prices [11,40,41]. Parker [11] and Jud and Winkler [40] claim that population growth is significantly correlated with the housing market. Takáts [41] notes that that demographic dividend serves as an important driving force behind housing prices. Zhang et al. [12] use a panel vector autoregression (PVAR) model to assess direct and indirect mechanisms of the demographic dividend that cause real estate price escalation. Their results show that the demographic dividend can increase housing prices though both direct and indirect channels.

In summary, we can examine determinants of housing prices from two perspectives: micro and macro perspectives. Micro-level studies focus on determinants of housing prices in a certain community or a district, while macro-level studies focus on determinants of average housing prices in the city or province levels. From both micro- and macro-level studies, we can conclude that factors that affect housing prices are quite extensive and micro-level factors such as building structure, distance to 
CBD, etc., are less important in macro-level studies. Hence, it is necessary for us to control as many factors as possible to assess the effect of rail transit on housing prices. However, most of the existing studies on the effect of transportation on housing prices have been conducted by case study on the base of micro-level data. To our knowledge, no studies have based on panel data at the city level. We thus conduct a study using city-level panel data and select an available proxy for rail transit facilities. To accurately assess impacts of urban rail transit services on housing prices, we consider possible factors based on previous studies. More specifically, we use selected factors as "control" variables in our panel data model.

\section{Urban Rapid Rail Transit in China}

\subsection{Rapid Rail Transit Development in China}

Beijing is home to the oldest metro rail transit system in China (established in 1969). It was initially developed as the capital's defence system for transporting troops when necessary. Management rights over the line were then transferred to a local transit company in 1977 and thereafter for public transit purposes. In China, rail transit line development has always constituted a major objective for city administrators. Through Chinese rail transit construction history; however, two setbacks occurred. Due to economic conditions and construction techniques employed at the time, the State Council suspended the approval of new rapid rail transit projects by publicizing the Notice of suspension for the approval of rapid rail transit projects in 1995. Prior to October of 2002, a number of cities published rail transit network plans and prepared for urban rail construction. To curb this new wave of rail transit construction, the State Council decided to freeze metro projects in certain cities (Hangzhou, Qingdao, and $\mathrm{Xi}^{\prime}$ an, among others).

After improvements were made to the rail transit project approval process, the urban rail transit system in China entered a phase of rapid expansion. As shown in Table 1, more and more cities opened rail transit lines after 2004. By the end of 2013, 23 cities had created rail transit lines, and more than 35 cities had published rail transit plans. Notably, cities that own rail transit networks are concentrated in eastern regions of China, implying that economic levels are a major determinant of rail transit construction. Along with the rapid development of urbanization in China, mass transit, and urban rail transit in particular, will certainly enter another golden era.

Table 1. Overview of urban rapid rail transit systems in China (by the end of 2013).

\begin{tabular}{cccccccccc}
\hline City & $\begin{array}{c}\text { Length } \\
\mathbf{( k m )}\end{array}$ & Lines & $\begin{array}{c}\text { Opening } \\
\text { Year }\end{array}$ & $\begin{array}{c}\text { City } \\
\text { Location }\end{array}$ & City & $\begin{array}{c}\text { Length } \\
\mathbf{( k m )}\end{array}$ & Lines & $\begin{array}{c}\text { Opening } \\
\text { Year }\end{array}$ & $\begin{array}{c}\text { City } \\
\text { Location }\end{array}$ \\
\hline Beijing & 465.0 & 17 & 1969 & Eastern & Wuhan & 72.1 & 4 & 2004 & Central \\
Tianjin & 142.6 & 4 & 2004 & Eastern & Guangzhou & 263.9 & 9 & 1997 & Eastern \\
Shenyang & 55.1 & 2 & 2010 & Eastern & Shenzhen & 173.1 & 5 & 2004 & Eastern \\
Dalian & 87.0 & 3 & 2002 & Eastern & Chongqing & 169.9 & 5 & 2004 & Western \\
Ha'erbin & 27.3 & 1 & 2013 & Eastern & Chengdu & 50.5 & 2 & 2010 & Western \\
Shanghai & 567.4 & 14 & 1993 & Eastern & Kunming & 38.5 & 3 & 2012 & Western \\
Nanjing & 108.6 & 2 & 2005 & Eastern & Xi'an & 45.5 & 2 & 2011 & Western \\
Hangzhou & 48.0 & 1 & 2013 & Eastern & Changchun & 47.9 & 5 & 2002 & Eastern \\
\hline
\end{tabular}

Source: Royal Flush iFind Database and Baidu Encyclopedia.

\subsection{The Correlation between Rail Transit Facilities and Housing Prices}

To achieve a basic understanding of the relationship between rail transit facilities and housing prices, we present temporal trends for the two variables (see Figure 1). Both total rail transit mileage levels and average housing prices have rapidly increased from 2002 to 2013. In regards to housing prices, the year 2008 can be considered the start of more significantly increasing housing price trends. In contrast, the turning point for rail transit mileage levels occurred in 2009. Similar characteristics for the two variables imply that there may be a high correlation between them. 


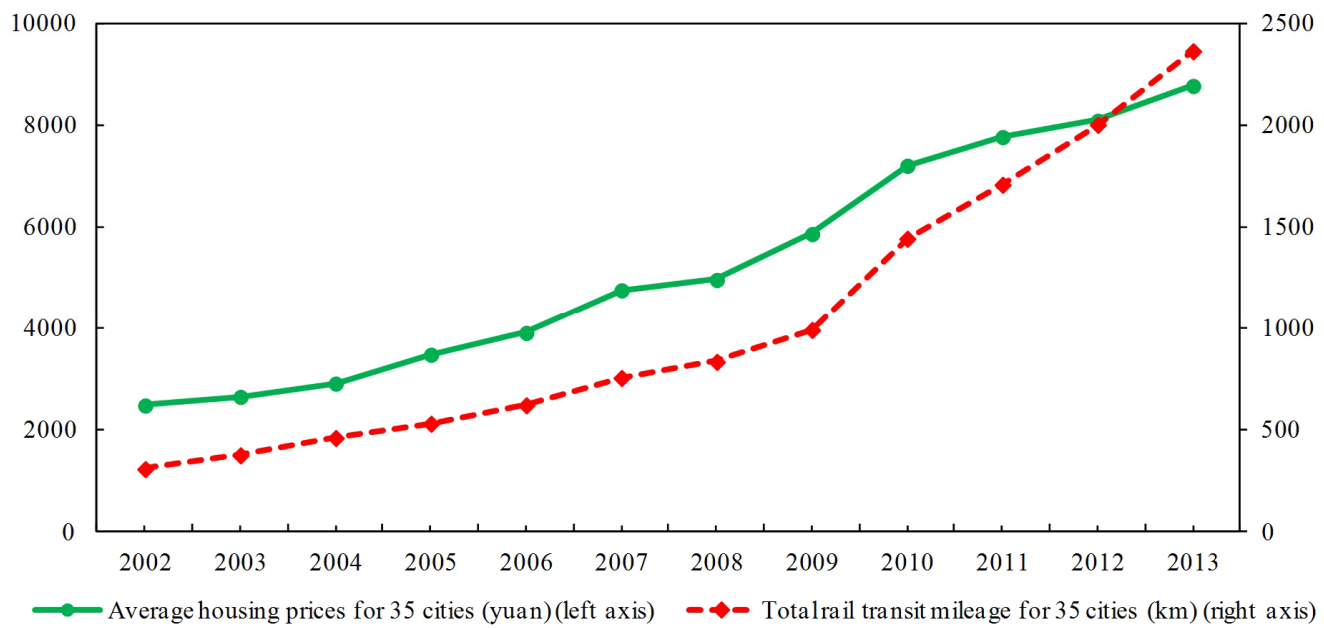

Figure 1. Total rail transit mileage records and average housing prices for 35 cities. Source: Royal Flush iFind Database [42] and China Real Estate Statistical Yearbook [43].

Table 2 presents Spearman correlational coefficients between rail transit mileage levels and housing prices for the cities that own metro lines. Overall, correlational coefficients in most of the cities are close to 1, and especially for larger cities, such as Beijing, Shanghai and Guangzhou, denoting a high correlation between rail transit facilities and housing prices. Next, we conduct a further analysis using an econometric model.

Table 2. Correlational coefficients for large cities.

\begin{tabular}{cccccc}
\hline City & Spearman & City & Spearman & City & Spearman \\
\hline \multirow{2}{*}{ Beijing } & $\begin{array}{c}0.9296^{* * *} \\
(7.9759)\end{array}$ & Wuhan & $\begin{array}{c}0.8005^{* * *} \\
(4.2231)\end{array}$ & Nanjing & $\begin{array}{c}0.9497^{* * *} \\
(9.5991)\end{array}$ \\
\hline \multirow{2}{*}{ Tianjin } & $\begin{array}{c}0.8503^{* * *} \\
(5.1098)\end{array}$ & Guangzhou & $\begin{array}{c}0.9736^{* * *} \\
(13.5017)\end{array}$ & Changchun & $\begin{array}{c}0.8753^{* * *} \\
(5.7254)\end{array}$ \\
\hline \multirow{2}{*}{ Dalian } & $\begin{array}{c}0.8849^{* * *} \\
(6.007)\end{array}$ & Shenzhen & $\begin{array}{c}0.9406^{* * *} \\
(8.7651)\end{array}$ & & \\
\hline \multirow{2}{*}{ Shanghai } & $\begin{array}{c}0.9555^{* * *} \\
(10.2445)\end{array}$ & Chongqing & $\begin{array}{c}0.9841^{* * *} \\
(17.5579)\end{array}$ & & \\
\hline
\end{tabular}

Spearman correlation coefficients were calculated using Eviews 6.0. ${ }^{* * *}$ denotes significance at the $1 \%$ level. $t$-statistics are reported in parentheses below correlational coefficients.

\section{Methodology and Data}

\subsection{Econometric Model Specification}

In light of the highly possible positive effect of rail transit facilities on housing prices, we use rail transit mileage as the main independent variable and economic fundamentals, demographic factors and educational resources as "control" variables. These variables are listed in Table 3. Our empirical model is described by the following equations:

$$
\begin{aligned}
\ln \text { housing }_{i t}= & c+\beta_{1} \ln g d p p_{i t}+\beta_{2} \text { unemploy }_{i t}+\beta_{3} \text { popgrowth }_{i t}+\beta_{4} \ln \text { popdensity } \\
& +\beta_{5} \ln \text { land }_{i t}+\beta_{6} \ln _{\text {invest }}+\beta_{7} \ln \text { college }_{i t}+\beta_{8} \ln \text { primary } \\
& \\
& +\beta_{9} \ln \text { book }_{i t}+\beta_{10} \ln \text { hospital }_{i t}+\beta_{11} \ln \text { rail }_{i t}+\alpha_{i}+\varepsilon_{i t}
\end{aligned}
$$

where the subscript $i$ indexes cities, $\alpha_{i}$ denotes an individual specific effect term and $\varepsilon_{i t}$ the error term. Panel data are also called cross-sectional time-series data. A panel data set contains $n$ entities or subjects, 
each of which includes $T$ observations measured at 1 through $t$ time period. Thus, the total number of observations in the panel data is $n \times T$. Cross-sectional data set is a type of one-dimensional data set and refers to a data set collected by observing subjects (such as individuals, firms or countries/regions at the same point of time. Panel data model and cross-sectional data model are econometric models estimated by various methods based on panel data set and cross-sectional data set, respectively. As noted above, the local government typically publishes rail transit network plans and construction periods a few years in advance. Thus, rail transit expectations may have unique effects on housing prices. We thus apply special specifications to the sample data by using the $\ln$ rail variable for the $n$ $(n=1,2,3)$ period when estimating the models.

Table 3. Definitions of variables.

\begin{tabular}{|c|c|c|}
\hline Catalogue & Variable & Description \\
\hline Dependent variable & Housing price (housingp) & $\begin{array}{l}\text { This variable represents an average price for } \\
\text { all commodity house types }\end{array}$ \\
\hline \multirow{3}{*}{ Economic factors } & GDP per capita $(g d p p)$ & This variable measures per capita GDP \\
\hline & Unemployment rate (unemploy) & $\begin{array}{l}\text { This variable presents the unemployed } \\
\text { population as a proportion of labourers }\end{array}$ \\
\hline & Land price (landp) & This variable represents the urban land price \\
\hline \multirow[t]{2}{*}{ Demographic factors } & Population growth rate (popgrowth) & $\begin{array}{l}\text { This variable represents the annual ratio of } \\
\text { natural demographic increase to the current } \\
\text { average population }\end{array}$ \\
\hline & Population density (popdensity) & $\begin{array}{l}\text { This variable measures population density } \\
\text { within a area of one square kilometre }\end{array}$ \\
\hline Housing market factors & $\begin{array}{l}\text { Completed investment in real estate } \\
\text { market (invest) }\end{array}$ & $\begin{array}{l}\text { This variable measures the annual investment } \\
\text { spending that has completed in the real estate } \\
\text { market, which differs from the planned } \\
\text { investment spending }\end{array}$ \\
\hline \multirow{3}{*}{ Educational factors } & Colleges per capita (college) & $\begin{array}{l}\text { This variable measures the number of } \\
\text { colleges and universities per capita }\end{array}$ \\
\hline & Primary schools per capita (primary) & $\begin{array}{l}\text { This variable measures the number of } \\
\text { primary schools per capita }\end{array}$ \\
\hline & Books per capita (book) & $\begin{array}{l}\text { This variable is a proxy of scientific resource } \\
\text { and indirectly measure the level of science, } \\
\text { technology and education in a certain city }\end{array}$ \\
\hline Health facility & Hospitals per capita (hospital) & $\begin{array}{l}\text { This variable measures the number of } \\
\text { hospitals per capita }\end{array}$ \\
\hline Rapid transit factor & Rail transit (rail) & $\begin{array}{l}\text { The variable measures the operation mileage } \\
\text { of rail transit systems }\end{array}$ \\
\hline
\end{tabular}

\subsection{Data and Descriptive Statistics}

Data for this study were gathered from the Royal Flush iFind Database [42], China Real Estate Statistical Yearbook [43], the China City Statistical Yearbook [44] and the China Statistical Yearbook [45], which includes data on 35 major Chinese cities for 2002 to 2013. To eliminate impacts of inflation on the economic variables, we treat 2000 as a base year and make price adjustments to the variables. We also use natural logarithms for the variables with the exception of those for unemployment and popgrowth. If one city does not own a metro line, variable values remain at zero.

This study models housing prices as a function of eleven explanatory variables (listed in Table 3). Table 4 shows the descriptive statistics for the variables used in this paper. The average housing price is $5,238.803$ yuan $/ \mathrm{m}^{2}$ for the sample period. The highest and lowest housing prices are 24,402 and 1464 yuan $/ \mathrm{m}^{2}$, respectively, denoting the existence of major housing price variations in different cities for the sample period. The per capita GDP level is 43,184.61 yuan. To compare the difference in the development of urban rapid rail transit between cities, we report the descriptive statistics for rail 
transit for the 35 cities and for the cities that have a rail transit system respectively. The means and standard deviations of rail transit for different groups are significantly distinguishing, which indicates a huge imbalance in the development of urban rail transit in China. On average, land prices are lower than housing prices and are more volatile than housing prices. It can be concluded that there are significant variations between the variables for the sample period.

Table 4. Descriptive statistics.

\begin{tabular}{lccccc}
\hline \multicolumn{1}{c}{ Variable } & Obs & Mean & Std. Dev. & Min & Max \\
\hline Housing price & 420 & 5238.80 & 3544.25 & 1464.00 & $24,402.00$ \\
\hline GDP per capita & 420 & $43,184.61$ & $25,982.08$ & 6027.00 & $153,206.00$ \\
\hline Unemployment rate & 420 & 2.9816 & 1.3016 & 0.4295 & 8.1423 \\
\hline Population growth rate & 420 & 5.0762 & 3.5636 & -3.31 & 19.80 \\
\hline Population density & 420 & 701.82 & 599.21 & 123.95 & 3809.08 \\
\hline Land price & 420 & 3685.84 & 3922.92 & 492.00 & $21,395.00$ \\
\hline $\begin{array}{l}\text { Completed investment in real } \\
\text { estate market }\end{array}$ & 420 & 530.82 & 584.20 & 14.83 & 3483.41 \\
\hline Colleges per capita & 420 & $5.83 \times 10^{-6}$ & $2.28 \times 10^{-6}$ & $9.31 \times 10^{-7}$ & $1.20 \times 10^{-5}$ \\
\hline Primary schools per capita & 420 & $1.74 \times 10^{-4}$ & $8.46 \times 10^{-5}$ & $4.32 \times 10^{-5}$ & $4.37 \times 10^{-4}$ \\
\hline Books per capita & 420 & 1.2631 & 1.2189 & 0.1252 & 9.3724 \\
\hline Hospitals per capita & 420 & $5.99 \times 10^{-5}$ & $7.21 \times 10^{-5}$ & $2.26 \times 10^{-5}$ & $7.28 \times 10^{-4}$ \\
\hline Rail transit for the 35 cities & 420 & 29.52 & 76.31 & 0 & 567.40 \\
\hline $\begin{array}{l}\text { Rail transit for the cities that have a } \\
\text { rail transit }\end{array}$ & 180 & 68.73 & 104.50 & 10.00 & 567.40 \\
\hline
\end{tabular}

To avoid estimation errors caused by a multicollinearity issue, we conduct a VIF (variance inflation factor) test and a correlational coefficient test. Tables 5 and 6 report the test results of VIF and correlational coefficient based on the pooled sample, respectively. From Table 5, we can observe that all VIF values are lower than 10 and the mean VIF is as low as 2.05, suggesting there doesn't exist a serious collinearity issue among the variables. In addition, the test results of correlational coefficients support the conclusion of the VIF test.

Table 5. Test results of variance inflation factor.

\begin{tabular}{cccccc}
\hline & VIF & 1/VIF & & VIF & 1/VIF \\
\hline $\operatorname{lngdpp}$ & 3.26 & 0.306333 & unemploy & 1.32 & 0.757158 \\
$\ln$ landp & 2.32 & 0.430743 & lnhospital & 1.39 & 0.721666 \\
$\ln$ invest & 3.9 & 0.256533 & lnprimary & 1.74 & 0.573883 \\
lnrail & 2.05 & 0.488405 & lncollege & 1.41 & 0.709692 \\
popgrowth & 1.38 & 0.725234 & lnbook & 1.99 & 0.502968 \\
lnpopdensity & 1.81 & 0.553413 & Mean VIF & 2.05 & \\
\hline
\end{tabular}


Table 6. Correlational coefficients between variables.

\begin{tabular}{|c|c|c|c|c|c|c|c|c|c|c|c|c|}
\hline & lnhousingp1 & $\ln g d p p$ & $\ln l a n d p$ & lninvest & $\ln r a i l$ & popgrowth & lnpopdensity & unemploy & $\ln$ hospital & lnprimary & lncollege & $\ln b o o k$ \\
\hline $\ln h o u s i n g p 1$ & 1 & & & & & & & & & & & \\
\hline $\ln g d p p$ & 0.89 & 1 & & & & & & & & & & \\
\hline $\ln l a n d p$ & 0.70 & 0.56 & 1 & & & & & & & & & \\
\hline lninvest & 0.77 & 0.73 & 0.66 & 1 & & & & & & & & \\
\hline lnrail & 0.50 & 0.49 & 0.38 & 0.61 & 1 & & & & & & & \\
\hline popgrowth & -0.10 & -0.15 & -0.24 & -0.32 & -0.33 & 1 & & & & & & \\
\hline lnpopdensity & 0.53 & 0.48 & 0.57 & 0.50 & 0.43 & -0.15 & 1 & & & & & \\
\hline unemploy & -0.44 & -0.32 & -0.37 & -0.26 & -0.06 & -0.15 & -0.13 & 1 & & & & \\
\hline lnhospital & -0.38 & -0.34 & -0.35 & -0.36 & -0.28 & 0.04 & -0.45 & 0.13 & 1 & & & \\
\hline lnprimary & -0.34 & -0.41 & -0.21 & -0.53 & -0.17 & 0.30 & -0.15 & 0.11 & 0.35 & 1 & & \\
\hline lncollege & 0.15 & 0.23 & -0.10 & -0.02 & -0.09 & 0.28 & 0.09 & -0.01 & 0.12 & -0.01 & 1 & \\
\hline $\ln b o o k$ & 0.52 & 0.58 & 0.33 & 0.34 & 0.39 & -0.14 & 0.30 & -0.13 & -0.08 & -0.06 & 0.30 & 1 \\
\hline
\end{tabular}




\section{Results and Discussion}

\subsection{Effects of Urban Rail Transit Facilities on Housing Prices}

The empirical analysis consists of two parts: the direct effects and the expectation effects of rail transit facilities on housing prices. First, we use a panel data model to assess the direct effect of rail transit facilities on housing prices. We use the average commercial housing prices (housingp1) as the explained variable. The coefficient on rail transit facilities is estimated when the effects of other variables listed in Table 3 are controlled. To check the robustness, we also use the residential housing prices (housingp2) as the explained variable instead of the average commercial housing prices. In China, commercial house refers to buildings used to reside or to generate a profit, either from capital gain or rental income. Residential house refers to commercial house with living space less than 144 square meters. Thus, the term commercial house has a larger scope than a residential house.

Table 7 reports the regression results. Models 1 and 2 are estimated by an ordinary least squares (OLS) estimator using a pooled sample. Random-effect models are shown in the fourth and fifth columns, respectively. Fixed-effect estimates are listed in the last two columns. For the case of this study, the functional form of fixed-effect model is $\operatorname{lnhousing} p_{i t}=\left(c+\alpha_{i}\right)+X_{i t}^{\prime} \beta+\varepsilon_{i t}$, while the functional form of random-effect model is $\operatorname{lnhousing} p_{i t}=c+X_{i t}^{\prime} \beta+\left(\alpha_{i}+\varepsilon_{i t}\right)$, where $X_{i t}^{\prime}$ denotes the explanatory variable vector, and $\alpha_{i}$ is a fixed or random effect specific to individual (group) or time period. Error variances in fixed-effect model are constant, and intercepts are varying across group or time. In contrast, error variances in random-effect model are randomly distributed across group or time, and intercepts are constant. If we put all the panel data together and do not make any distinction between cross section and time series, we can of course run a regression over all the data using ordinary least squares. This is called a pooled OLS regression. Pooled OLS is often used as a rough and ready means of analyzing the data. It is a simple and quick benchmark to which more sophisticated regressions can be compared. The Hausman test for models with lnhousingp 1 as the explained variable suggests that fixed-effect models exhibit better performance than the random-effect models. In contrast, the Hausman test for models with lnhousingp 2 as the explained variable suggests that random-effect models exhibit better performance than fixed-effect models. According to the $F$ statistic, we fail to reject the null hypothesis of coefficients being zero at the $1 \%$ level. The adjusted $R^{2}$ of each model are greater than 0.85 . In particular, the adjusted $R^{2}$ for the suggested model (Model 3a) by Hausman test is as high as 0.8636 , which indicates that all the independent variables can explain the housing prices variation by $86.36 \%$. Overall, most of the coefficients on the "control" variables in the fifth column are significant at the $5 \%$ level or better and have the expected signs.

We shift focus to the impact of urban rail transit facilities on housing prices. The significance of the coefficient on lnrail in Model 3a precisely verifies our previous deduction. The sign on the coefficient, as expected, is positive, which is consistent with the findings in the case study documented by Seo et al. [19]. The magnitude of the coefficient is 0.0233 , which means that each one-degree increase in rail transit mileage improves housing prices by $0.0233 \%$. The coefficient, as one would expect, is much smaller in value than most of the other variables, such as per capita GDP, land price, completed investment and population growth, indicating that urban rapid trail transit generates relatively small but significant impact on housing prices. These findings suggest that economic factors such as income, population growth and employment are major determinants of housing prices.

The significant impact of urban rail transit facilities on housing prices suggests that the development of urban rail transit network plays an important role in house price increases in China during the past decade. Consequently, how the rail transit facilities influence the housing price is what we are interested in. There exist two possible channels (direct and scale effects) through which urban rail transit facilities affect housing prices. As previous case studies have shown, one's proximity to transportation nodes is significantly and positively associated with housing prices, and we refer to this as a direct effect. Compared to other transportation instruments (e.g., bus rail transit systems), metro rail transit systems have an entirely different impact on human activities and even on economic 
growth patterns. That is, metro rail transit systems extend the boundaries of urban functions due to their speed advantages relative to other mass transit systems, resulting in the convergence of suburban housing prices to central areas. From a microeconomics perspective, metro line system expansions may result in scale effects on housing prices. First, rail transit network developments create extra amenities that may lead to the development of additional accessibility premiums. Second, in terms of ripple effects, rail transit network expansion causes housing prices farther from stations to rise.

Table 7. Regression results of the basic models.

\begin{tabular}{|c|c|c|c|c|c|c|}
\hline \multirow{2}{*}{ Model } & \multicolumn{2}{|c|}{ Pooled-OLS } & \multicolumn{2}{|c|}{ Random-Effects } & \multicolumn{2}{|c|}{ Fixed-Effect } \\
\hline & $1 a$ & $1 b$ & $2 a$ & $2 b$ & $3 a$ & $3 b$ \\
\hline explained variable & $\operatorname{lnhousingp1}$ & $\operatorname{lnhousingp2}$ & $\operatorname{lnhousingp1}$ & $\ln h o u \operatorname{singp} 2$ & $\ln h o u \operatorname{sing} p 1$ & $\ln h o u s i n g p 2$ \\
\hline $\ln g d p p$ & $\begin{array}{c}0.4733^{* * *} \\
(-16.6)\end{array}$ & $\begin{array}{c}0.4890^{* * *} \\
(-16.39)\end{array}$ & $\begin{array}{c}0.3689 * * * \\
(-8.99)\end{array}$ & $\begin{array}{c}0.3699 * * * \\
(-8.71)\end{array}$ & $\begin{array}{c}0.2486^{* * *} \\
(-5)\end{array}$ & $\begin{array}{c}0.2481^{* * *} \\
(-4.77)\end{array}$ \\
\hline $\ln l a n d p$ & $\begin{array}{c}0.1644 * * * \\
(-9.64)\end{array}$ & $\begin{array}{c}0.1779 * * * \\
(-9.96)\end{array}$ & $\begin{array}{c}0.2320 * * * \\
(-8.6)\end{array}$ & $\begin{array}{c}0.2386^{* * *} \\
(-8.55)\end{array}$ & $\begin{array}{c}0.3110^{* * *} \\
(-9.17)\end{array}$ & $\begin{array}{c}0.3179^{* * *} \\
(-8.95)\end{array}$ \\
\hline lninvest & $\begin{array}{c}0.0641^{* * *} \\
(-4.05)\end{array}$ & $\begin{array}{c}0.0588^{* * *} \\
(-3.55)\end{array}$ & $\begin{array}{c}0.0907^{* * *} \\
(-4.02)\end{array}$ & $\begin{array}{c}0.1070^{* * *} \\
(-4.58)\end{array}$ & $\begin{array}{c}0.1182 * * * \\
(-4.15)\end{array}$ & $\begin{array}{c}0.1392^{* * *} \\
(-4.67)\end{array}$ \\
\hline $\ln r a i l$ & $\begin{array}{c}0.0298^{* * *} \\
(-4.57)\end{array}$ & $\begin{array}{c}0.0261 * * * \\
(-3.82)\end{array}$ & $\begin{array}{c}0.0216^{* * *} \\
(-2.69)\end{array}$ & $\begin{array}{l}0.0147^{*} \\
(-1.76)\end{array}$ & $\begin{array}{c}0.0233 * * * \\
(-2.65)\end{array}$ & $\begin{array}{l}0.0163 * \\
(-1.77)\end{array}$ \\
\hline popgrowth & $\begin{array}{c}0.0193 \text { *** } \\
(-6.61)\end{array}$ & $\begin{array}{c}0.0201^{* * * *} \\
(-6.58)\end{array}$ & $\begin{array}{c}0.0151^{* * * *} \\
(-4.73)\end{array}$ & $\begin{array}{c}0.0165^{* * *} \\
(-4.96)\end{array}$ & $\begin{array}{c}0.0079 * * \\
(-2.26)\end{array}$ & $\begin{array}{c}0.0097^{* * *} \\
(-2.64)\end{array}$ \\
\hline lnpopdensity & $\begin{array}{c}0.0356^{* *} \\
(-2.08)\end{array}$ & $\begin{array}{c}0.0523^{* * *} \\
(-2.92)\end{array}$ & $\begin{array}{l}0.0282 \\
(-0.9)\end{array}$ & $\begin{array}{c}0.0326 \\
(-1.01)\end{array}$ & $\begin{array}{l}0.0798^{*} \\
(-1.8)\end{array}$ & $\begin{array}{c}0.0727 \\
(-1.57)\end{array}$ \\
\hline unemploy & $\begin{array}{c}-0.0424^{* * *} \\
(-5.41)\end{array}$ & $\begin{array}{c}-0.0452^{* * *} \\
(-5.51)\end{array}$ & $\begin{array}{c}-0.0341^{* * *} \\
(-4.26)\end{array}$ & $\begin{array}{c}-0.0373^{* * *} \\
(-4.47)\end{array}$ & $\begin{array}{c}-0.0303^{* * *} \\
(-3.66)\end{array}$ & $\begin{array}{c}-0.0334^{* * *} \\
(-3.86)\end{array}$ \\
\hline Incollege & $\begin{array}{l}-0.0147 \\
(-0.63)\end{array}$ & $\begin{array}{l}-0.0132 \\
(-0.54)\end{array}$ & $\begin{array}{l}0.00529 \\
(-0.16)\end{array}$ & $\begin{array}{c}0.0217 \\
(-0.62)\end{array}$ & $\begin{array}{l}-0.0141 \\
(-0.34)\end{array}$ & $\begin{array}{l}0.00778 \\
(-0.18)\end{array}$ \\
\hline lnprimary & $\begin{array}{c}0.0794 \\
(-1.65) \\
\end{array}$ & $\begin{array}{c}0.0434 \\
(-0.86) \\
\end{array}$ & $\begin{array}{c}-0.202 \text { ** } \\
(-2.51)\end{array}$ & $\begin{array}{c}-0.182 \text { ** } \\
(-2.20)\end{array}$ & $\begin{array}{c}-0.444^{* * *} \\
(-4.31)\end{array}$ & $\begin{array}{c}-0.394^{* * *} \\
(-3.66)\end{array}$ \\
\hline lnhospital & $\begin{array}{c}0.0104 \\
(-0.49)\end{array}$ & $\begin{array}{l}-0.0102 \\
(-0.46)\end{array}$ & $\begin{array}{c}0.0207 \\
(-0.92)\end{array}$ & $\begin{array}{l}0.0029 \\
(-0.12)\end{array}$ & $\begin{array}{c}0.0337 \\
(-1.45)\end{array}$ & $\begin{array}{c}0.0163 \\
(-0.67)\end{array}$ \\
\hline $\ln b o o k$ & $\begin{array}{c}0.0442 * * \\
(-2.52)\end{array}$ & $\begin{array}{c}0.0470 * * \\
(-2.56)\end{array}$ & $\begin{array}{c}0.0891 * * * \\
(-4.62)\end{array}$ & $\begin{array}{c}0.103^{* * *} \\
(-5.12)\end{array}$ & $\begin{array}{c}0.103^{* * *} \\
(-5.06)\end{array}$ & $\begin{array}{l}0.121^{* * *} \\
(-5.68)\end{array}$ \\
\hline constant & $\begin{array}{l}1.260^{* * * *} \\
(-4.32)\end{array}$ & $\begin{array}{l}0.953^{* * * *} \\
(-3.12)\end{array}$ & $\begin{array}{l}2.060^{* * * *} \\
(-4.82)\end{array}$ & $\begin{array}{c}1.768^{* * * *} \\
(-4)\end{array}$ & $\begin{array}{l}2.641^{* * *} \\
(-4.96)\end{array}$ & $\begin{array}{c}2.334^{* * *} \\
(-4.19)\end{array}$ \\
\hline Obs. & 420 & 420 & 420 & 420 & 420 & 420 \\
\hline F/Wald-statistic & $281.65^{* * *}$ & $281.59 * * *$ & $2439.09 * * *$ & $2487.53^{* * *}$ & $215.31^{* * *}$ & $217.06^{* * *}$ \\
\hline Adjusted- $R^{2}$ & 0.8805 & 0.8805 & 0.8575 & 0.8595 & 0.8636 & 0.8646 \\
\hline Hausman test & $34.12 * * *$ & 6.36 & $34.12 * * *$ & 6.36 & $34.12 * * *$ & 6.36 \\
\hline
\end{tabular}

Some other findings are noteworthy. First, economic fundamentals such as per capita GDP and unemployment rate exhibit strong effects on the property values. Meanwhile, land price, as the cost proxy, shows strong impact on housing prices, which supports the view that cost drives housing prices $[9,29,30]$. Theses findings are consistent with the view that economic fundamentals are the major driving factors in determining housing prices [31-34]. Second, the coefficient on population is significant and presents the expected sign, which indicates that the demographic factors play an important role in forming housing price bubbles. 
Third, housing market factors show strong effects on housing prices. Completed investment in housing markets demonstrates a notable effect, which, to some extent, reflects the developers' expectations of housing prices. Fourth, scientific resource measured by books per capita generates a significantly positive impact on housing prices. In contrast, the effect of health facility per capita is insignificant. Fifth, the variable primary school per capita generates a significantly negative effect on housing prices, while the effect of the variable colleges per capita is insignificant. These findings imply that the scarcity of primary educational resource may increase housing prices, which is remarkably different from the effects of health facility per capita and scientific resource per capita. From the data set, we observe that the variable primary school per capita shows a diminishing trend with the population growth, which is opposite to health facility per capita and scientific resource per capita. Indeed, if the primary educational resource per capita is scarcer, the houses near the primary school are more expensive in China, which is more obvious in large cities.

\subsection{Rail Transit Expectation Effects on Housing Prices}

Real estate developers in China are keen to broadly advertise metro housing facilities from the planning of a rail transit line to its opening. While a metro line generally takes approximately 3-4 years to construct, overall transit network plans may be designed a few years earlier. As a result, the public is well informed of plans and of expected opening dates, resulting in differences between this variable and other endogenous variables. Thus, it is of enormous interest to investigate premiums of rail transit facilities on housing prices from the perspective of expectation.

To assess the impact of the expectation of new metro lines on housing price, we estimate different models with different expectation specification. Table 8 reports the estimates with fixed-effect specification. From the estimates of Model 5, the coefficient on lnrail is not significant at any significant levels, indicating that expectations of new metro lines 1 year prior to opening cannot generate significant effects on housing prices. Similar situations can be found in Models 6 and 7. Furthermore, coefficients on lnrail present a diminishing trend form Model 4 to Model 7, which seems to show that, with the planning of new lines, rail transit facilities generate more and more effects on housing prices, although most of the coefficients are insignificant.

Table 8. Regression results of the models that consider the expectation of new rail lines.

\begin{tabular}{ccccc}
\hline Model & $\mathbf{4}$ & $\mathbf{5}$ & $\mathbf{6}$ & $\mathbf{7}$ \\
\hline \multirow{2}{*}{$\ln g d p p$} & $0.2486^{* * *}$ & $0.276^{* * *}$ & $0.277^{* * *}$ & $0.264^{* * *}$ \\
\cline { 2 - 5 } & $(-5)$ & $(-5.19)$ & $(-4.87)$ & $(-3.04)$ \\
\hline \multirow{2}{*}{$\ln$ landp } & $0.3110^{* * *}$ & $0.389^{* * *}$ & $0.446^{* * *}$ & $0.535^{* * *}$ \\
\cline { 2 - 5 } & $(-9.17)$ & $(-9.89)$ & $(-9.38)$ & $(-4.6)$ \\
\hline \multirow{2}{*}{$\ln$ invest } & $0.1182^{* * *}$ & $0.117^{* * *}$ & $0.103^{* * *}$ & 0.0768 \\
\cline { 2 - 5 } & $(-4.15)$ & $(-4.01)$ & $(-3.24)$ & $(-1.16)$ \\
\hline \multirow{2}{*}{$\ln$ rail } & $0.0233^{* * *}$ & 0.0133 & 0.0108 & 0.00875 \\
\cline { 2 - 5 } & $(-2.65)$ & $(-1.41)$ & $(-1)$ & $(-0.42)$ \\
\hline \multirow{2}{*}{ popgrowth } & $0.0079^{* *}$ & $0.00930 * *$ & $0.00868^{*}$ & 0.00574 \\
\cline { 2 - 5 } & $(-2.26)$ & $(-2.5)$ & $(-1.97)$ & $(-1.1)$ \\
\hline \multirow{2}{*}{$\ln$ *opdensity } & $0.0798^{*}$ & 0.0648 & 0.0309 & -0.024 \\
\cline { 2 - 5 } & $(-1.8)$ & $(-1.26)$ & $(-0.56)$ & $(-0.33)$ \\
\hline \multirow{2}{*}{ unemploy } & $-0.0303^{* * *}$ & $-0.0283^{* * *}$ & $-0.0257^{* * *}$ & -0.0197 \\
\cline { 2 - 5 } & $(-3.66)$ & $(-3.31)$ & $(-2.82)$ & $(-1.24)$ \\
\hline
\end{tabular}


Table 8. Cont.

\begin{tabular}{ccccc}
\hline Model & $\mathbf{4}$ & 5 & $\mathbf{6}$ & $\mathbf{7}$ \\
\hline \multirow{2}{*}{$\ln$ college } & -0.0141 & -0.0245 & -0.0212 & $-2.8 \mathrm{E}-05$ \\
\cline { 2 - 5 } & $(-0.34)$ & $(-0.59)$ & $(-0.50)$ & $(-0.00)$ \\
\hline \multirow{2}{*}{$\ln$ primary } & $-0.444^{* * *}$ & $-0.384^{* * *}$ & $-0.414^{* * *}$ & $-0.475^{* *}$ \\
\cline { 2 - 5 } & $(-4.31)$ & $(-3.56)$ & $(-3.52)$ & $(-2.13)$ \\
\hline \multirow{2}{*}{$\ln h o s p i t a l$} & 0.0337 & 0.0322 & 0.0292 & 0.0331 \\
\cline { 2 - 5 } & $(-1.45)$ & $(-1.37)$ & $(-1.17)$ & $(-1.2)$ \\
\hline \multirow{2}{*}{$\ln$ book } & $0.103^{* * *}$ & $0.135^{* * *}$ & $0.168^{* * *}$ & $0.195^{* * *}$ \\
\cline { 2 - 5 } & $(-5.06)$ & $(-5.89)$ & $(-5.77)$ & $(-3.13)$ \\
\hline \multirow{2}{*}{ constant } & $2.641^{* * *}$ & $1.701^{* * *}$ & $1.524^{* *}$ & 1.462 \\
\cline { 2 - 5 } & $(-4.96)$ & $(-2.98)$ & $(-2.47)$ & $(-1.65)$ \\
\hline Obs. & 420 & 385 & 350 & 315 \\
\hline F-statistic & $215.31^{* * *}$ & $190.74^{* * *}$ & $151.36^{* * *}$ & $72.82^{* * *}$ \\
\hline Adjusted- $R^{2}$ & 0.8636 & 0.8609 & 0.8456 & 0.8296 \\
\hline
\end{tabular}

$t$-statistics are reported in parentheses below the coefficient estimates. ${ }^{*}, * *$ and ${ }^{* * *}$ denote significance at the $10 \%, 5 \%$ and $1 \%$ levels, respectively. Models $4,5,6$, and 7 present the models based on current-period, one-period-ahead, two-period-ahead and three-period-ahead rail transit data, respectively.

\section{Conclusions}

The purpose of this study is to measure effects of urban rail infrastructure on housing values using a panel data model on 35 Chinese cities for 2002 to 2013. Previous studies have focused on relationships between urban transit systems and housing prices (e.g., between housing prices and high speed railway systems [20], road and rail systems [20], rail accessibility levels [46-48], and highway and light rail accessibility levels [49]. However, nearly all of the studies presented above are case studies. To our knowledge, no city-level panel data have been used to assess urban rail transit system impacts on housing prices. During estimation, numerous independent variables selected based on the existing literature were included to control and measure rail transit effects.

The main results of the study show that the rail transit facilities have significantly positive effects on housing prices. Quantitatively, each $1 \%$ increase in rail transit mileage improves housing prices by $0.0233 \%$. As one would expect, such effects are smaller than those of some other variables such as per capita GDP, land price, real estate investment and population growth, which are recognized as fundamental determinants of housing price. We also determine whether rail transit expectations have significant effects on housing prices and use various sample specifications to test expectation effects. The expectations of new rail transit lines cannot generate statistically significant effects on housing price. It can be concluded that urban rail transit systems play an indispensable role in determining housing prices.

This study is of practical significance, as it provides relative information for policy makers to use when applying regulatory powers to improve urban functions while stabilizing real estate prices. First, the central government should take utmost precautions to mitigate economic fluctuations. Second, local governments should increase or reduce the supply of urban land to affect land prices and the cost of development according to changes in real estate market conditions. Third, in order to mitigate real estate bubbles in big cities with highly-concentrated resources like Beijing, Shanghai, Guangzhou and Shenzhen, the central government should allocate more infrastructure spending, education and human resources to small cities. Fourth, the urban governor should take measures to control demographic growth, which contributes to stabilize housing prices and to increase the infrastructure per capita. The results of this study may also help home buyers select reasonable times and locations in making beneficial housing purchases. As China's real estate bubble is at risk of bursting, it is necessary for 
policy makers to take the endogenous factors such as urban rail transit into account and to diminish such threats to the housing market. The findings of this study can help home buyers and investors reasonably evaluate the value of rail accessibility.

Acknowledgments: We gratefully acknowledge the financial support from the National Natural Science Foundation of China (No.71473036). The authors are grateful to three anonymous reviewers whose comments have helped to improve the manuscript.

Author Contributions: In this paper, $\mathrm{Xu}$ Zhang designed the research programs, analyzed the results, and completed the writing of the results and discussion; Xiaoxing Liu committed to the data collection and completed the writing of the introduction; Jianqin Hang carried out the data process and completed the writing work of corresponding parts; Dengbao Yao and Guangping Shi completed the writing of Sections 2 and 3. Both authors have read and approved the final manuscript.

Conflicts of Interest: The authors declare no conflict of interest.

\section{References}

1. Yigitcanlar, T.; Kamruzzaman, M.; Teriman, S. Neighborhood sustainability assessment: Evaluating residential development sustainability in a developing country context. Sustainability 2015, 7, 2570-2602. [CrossRef]

2. Wei, Y.; Huang, C.; Lam, P.T.; Sha, Y.; Feng, Y. Using urban-carrying capacity as a benchmark for sustainable urban development: An empirical study of Beijing. Sustainability 2015, 7, 3244-3268. [CrossRef]

3. Shimizu, C. Estimation of Hedonic single-family house price function considering neighborhood effect variables. Sustainability 2014, 6, 2946-2960. [CrossRef]

4. Shen, L. Are house prices too high in China? China Econ. Rev. 2012, 23, 1206-1210. [CrossRef]

5. Ren, Y.; Xiong, C.; Yuan, Y. House price bubbles in China. China Econ. Rev. 2012, 23, 786-800. [CrossRef]

6. Feng, Q.; Wu, G. Bubble or riddle? An asset-pricing approach evaluation on China's housing market. Econ. Modell. 2015, 46, 376-383. [CrossRef]

7. Quigley, J. A simple hybrid model for estimating real estate price indexes. J. Hous. Econ. 1995, 4, 1-12. [CrossRef]

8. Leung, C.K.Y. Economic growth and increasing housing prices. Pac. Econ. Rev. 2003, 8, 183-190. [CrossRef]

9. Glaeser, E.L.; Gyourko, J.; Saks, R.E. Urban growth and housing supply. J. Econ. Geo. 2006, 6, 71-89.

10. Tan, Z.; Wu, S. A comparison of two housing markets. Appl. Econ. Lett. 2014, 21, 118-124. [CrossRef]

11. Parker, J.A. Comments and discussion on: Case KE. Brook. Pap. Econ. Act. 2000, 2, 146-159. [CrossRef]

12. Zhang, Y.; Liu, X.; Ding, Y.; Su, A. Assessing the impact of the demographic dividend on real estate prices: Empirical evidence from China. Appl. Econ. Lett. 2015, 22, 1450-1456. [CrossRef]

13. Huston, J.H.; Spencer, R.W. Housing and behavioral factors. Appl. Econ. Lett. 2014, 21, 215-219. [CrossRef]

14. Zhang, M.; Meng, X.; Wang, L.; Xu, T. Transit development shaping urbanization: Evidence from the housing market in Beijing. Habitat Int. 2014, 44, 545-554. [CrossRef]

15. Hewitt, C.M.; Hewitt, W.E. The effect of proximity to urban rail on housing prices in Ottawa. J. Publ. Trans. 2012, 15, 43-65. [CrossRef]

16. Jun, M. Redistributive effects of bus rapid transit (BRT) on development patterns and property values in Seoul, Korea. Transp. Policy 2012, 19, 85-92. [CrossRef]

17. Kim, K.; Lahr, M. The impact of Hudsone-Bergen light rail on residential property appreciation. Pap. Reg. Sci. 2013. [CrossRef]

18. Chatman, D.; Tulach, N.; Kim, K. Evaluating the economic impacts of light rail by measuring home appreciation: A first look at New Jersey's River Line. Urban Stud. 2012, 49, 467-487. [CrossRef]

19. Seo, K.; Golub, A.; Kuby, M. Combined impacts of highways and light rail transit on residential property values: A spatial hedonic price model for Phoenix, Arizona. J. Trans. Geo. 2014, 41, 53-62. [CrossRef]

20. Andersson, D.E.; Shyr, O.F.; Fu, J. Does high-speed rail accessibility influence residential property prices? Hedonic estimates from southern Taiwan. J. Trans. Geo. 2010, 18, 166-174. [CrossRef]

21. Lewis-Workman, S.; Brod, D. Measuring the neighbourhood benefits of rail transit accessibility. J. Transp. Res. Board 1997, 1576, 147-153. [CrossRef]

22. Zheng, J.; Liu, H. Impacts of Shenzhen metro rail on housing price. J. Chn. Rail. Soc. 2005, 27, 11-18. (In Chinese)

23. Zhang, H.; Ma, J.; Zhu, H. Price influence of urban mass transit on housing projects along the line. J. Beijing Jiaotong Univ. 2007, 31, 10-13. (In Chinese) 
24. Zhang, M. Bus versus rail: Meta-analysis of cost characteristics, carrying capacities, and land use impacts. Transp. Res. Rec. J. Transp. Res. Board Natl. Acad. 2009, 2110, 87-95. [CrossRef]

25. De Vany, A.S. An economic model of airport noise pollution in an urban environment. In Theory and Measurement of Economic Externalities; Lin, S.A.Y., Ed.; Academic Press: New York, NY, USA, 1976; pp. 205-216.

26. Wen, H.Z.; Jia, S.H. Housing characteristics and hedonic price: Based on hedonic price model. J. Zhejiang Unive. (Eng. Sci.) 2004, 38, 38-42. (In Chinese)

27. Feng, H.; Lu, M. Choose a school through buying a house: Evidences and policy implications of how education effect the housing price. World Econ. 2010, 12, 89-104.

28. Wen, H.; Zhang, Y.; Zhang, L. Do educational facilities affect housing price? An empirical study in Hangzhou, China. Habitat Int. 2014, 42, 155-163. [CrossRef]

29. Quigley, J.M. Real estate prices and economic cycles. Int. Re. Est. Rev. 1999, 2, 1-20.

30. Fortura, P.; Kushner, J. Canadian inter-city house price differentials. Am. Real Estate Urban Econ. Assoc. J. 1986, 14, 525-536. [CrossRef]

31. Zou, G.L.; Chau, K.W. Determinants and sustainability of house prices: The case of Shanghai, China. Sustainability 2015, 7, 4524-4548. [CrossRef]

32. Hwang, M.; Quigley, J. Economic fundamentals in local housing markets: Evidence from US metropolitan regions. J. Reg. Sci. 2006, 46, 425-453. [CrossRef]

33. Ceron, J.A.; Suarez, J. Hot and Cold Housing Markets: International Evidence; Centre for Economic Policy Research: Washington, DC, USA, 2006; Volume 5411.

34. Agnello, L.; Schuknecht, L. Booms and busts in housing markets: Determinants and implications. J. Hous. Econ. 2011, 20, 171-190. [CrossRef]

35. Kasparova, D.; White, M. The responsiveness of house prices to macroeconomic forces: A cross-country comparison. Eur. J. Hous. Poli. 2001, 1, 385-416. [CrossRef]

36. Yang, S. Objectively look on the problem of rising housing price. China Re. Est. Inf. 2003, 2, 4-5.

37. Bao, Z.H. How to look on housing price in our country. China Re. Est. 2004, 1, 18-19.

38. Wen, H.; Goodman, A.C. Relationship between urban land price and housing price: Evidence from 21 provincial capitals in China. Habitat Int. 2003, 40, 9-17. [CrossRef]

39. Du, H.; Ma, Y.; An, Y. The impact of land policy on the relation between housing and land prices: Evidence from China. Q. Rev. Econ. Financ. 2011, 51, 19-27. [CrossRef]

40. Jud, D.; Winkler, D. The dynamics of metropolitan housing prices. J. Real Est. Res. 2002, 23, $29-45$.

41. Takáts, E. Aging and house prices. J. Hous. Econ. 2012, 21, 131-141. [CrossRef]

42. Economic database. Royal Flush iFind Database. Available online: http://www.51ifind.com (accessed on 18 April 2016).

43. National Bureau of Statistics of China. China Real Estate Statistical Yearbook, 2003-2014; China Statistics Press: Beijing, China, 2003-2014.

44. National Bureau of Statistics of China. China City Statistical Yearbook, 2003-2014; China Statistics Press: Beijing, China, 2003-2014.

45. National Bureau of Statistics of China. China Statistical Yearbook, 2003-2014; China Statistics Press: Beijing, China, 2003-2014.

46. Cervero, R. Transit-based housing in the San Francisco bay area: Market profiles and rent premiums. Trans. $Q$. 1996, 50, 33-47.

47. Hess, D.B.; Almeida, T.M. Impact of proximity to light rail rapid transit on station-area property values in Buffalo, New York. Urban Study 2007, 44, 1041-1068. [CrossRef]

48. Golub, A.; Guhathakurta, S.; Sollapuram, B. Spatial and temporal capitalization effects of light rail in Phoenix: From conception, planning, and construction to operation. J. Plan. Edu. Res. 2012, 32, 415-429. [CrossRef]

49. Ryan, S. The value of access to highways and light rail transit: Evidence for industrial and office firms. Urban Study 2005, 42, 751-764. [CrossRef]

(C) 2016 by the authors; licensee MDPI, Basel, Switzerland. This article is an open access article distributed under the terms and conditions of the Creative Commons Attribution (CC-BY) license (http:/ / creativecommons.org/licenses/by/4.0/). 